TADEUSZ ŚLIPKO

\title{
ETHOS, BOUNDARIES AND PRACTICAL TASKS OF PATRIOTISM*
}

\begin{abstract}
The main thesis of this article states that patriotism constitutes a key role in the process of globalization. The author perceives the moral dimension of nation and homeland categories as the validation of such a position. Patriotism, which is not chauvinism, deeply connects with its own nation, as well as homeland, and due to its very nature, should be open to foreigners and other nations.
\end{abstract}

Keywords: patriotism; nation; homeland; morality

1. Introduction. 2. The nation as a social entity. 3. The nation vs. homeland. 4. The nation as a moral good. 5. The moral ethos and limitation of patriotism. 6 . Patriotism and threats to the national culture. 7. Conclusions.

\section{INTRODUCTION}

The introduction will comprise the account from six publications, the main idea of which is formed by two characteristic sequences of opposing views on the issue of patriotism.

Over one and a half centuries ago, Karol Libelt's dissertation entitled O mitosici ojczyzny [On the Love for Homeland] was published. In the introduction, this Polish Hegelian explains the motives which prompted him to undertake the topic included in the thesis' title. "There are people", writes the author, "who regard themselves as enlightened, who ... call national relations and interests a limitation of progress, detrimental to humanity, particularly to a nation blinded by patriotism and fiercely defending its particularist interests. They regard what we call native as having no basis. It is not language, ...

\footnotetext{
* This article was originally published in Polish as: T. Ślipko, Patriotyzmu etos, granice i praktyczne zadania, Studia Philosophiae Christianae 39(2003)2, 37-53. The translation of the article into English was financed by the Ministry of Science and Higher Education of the Republic of Poland as part of the activities promoting science - Decision No. 676/P-DUN/2019 of 2 April 2019. Translation made by GROY Translations.
} 
religion, ... geographical location, ... customs. Then, what is this delusional homeland, in the name of which we separate ourselves and do not connect with other nations, which have outrun us in education, which holds material and moral power, in hands of which the fate of humanity is placed .... This is how cosmopolitan thinkers reason"1.

In turn, in 1924, the Austrian political scientist R. N. Coudehove-Kalergi in his book Pan-Europa outlined a great picture of the supranational political structure of "Pan-Europe", in which he devoted a separate chapter to the issue of nationality. The theme of his views comprised the idea that the essence of a nation is founded on a spiritual community, shaped by the mutual relations between great people - to be more precise, brilliant leaders, poets, thinkers and people with a specific genius ${ }^{2}$. In the historical development, the national communities of Europe were formed under the influence of various factors. In the Middle Ages, this function was performed by the Christian cult of the sacrum while the symbol of national unity comprised of the "cathedral", as a place of religious worship. At that time, Europe consisted of one nation. With the split of Christianity and the secularity of Europe, Enlightenment rationalism shifted the focus of the national bond towards a creative spirit. At that moment, the "cathedrals", now associated with universities, raised to the rank of forges, creating the new shape of culture and its symbol, while transformations resulted in a multitude of individualized nations ${ }^{3}$. However, the new socio-political situation which followed the First World War postulated to undertake one more step in the national evolution: to deepen and broaden national cultures by providing them with the characteristics of European culture as a new whole $e^{4}$. This process was to be accomplished by neutralizing as many different components in national cultures, as needed to form a new, great pan-European na-

1 Re-issue of the dissertation O miłości ojczyzny, in: K. Libelt, Samowładztwo rozumu i objawy filozofii słowiańskiej, Warszawa 1967, 6 f.

2 R. N. Coudenhove-Kalergi, Pan-Europa, Wien - Leipzig 1924, 137.

3 Ibid, 139.

4 Ibid, 142. 
tion, or rather a "super nation" 5 . Therefore, it is a vision of a macro national cultural creation, in which the existing nations would not disappear, but function as purely regional communities.

At last, the third publication. It comprises a recently published book by Andrzej Olechowski, entitled Wygraćprzysztos ${ }^{6}$. What is the author's vision of the nation in the context of economic and political changes which take place today? The answer is: he does not outline any. It is difficult to consider as such a mention, in which the author predicts that "communities which choose to base their consciousness on the bonds and customs of tribal nature" ${ }^{7}$ are condemned to lose the opportunity to improve their international position. Therefore, participation in the European Union becomes an imperative of patriotism for the members of a nation "which for years has not existed on the political map". Then, in the final phase of reflection, he addresses the issue of the "national consciousness", he confines himself to confessing, that "we refer to something we cannot define". After such a declaration, it is not clear what is the author's basis for his optimistic conclusion that a person can be "authentic, responsible with regard to their origin, past and cultural heritage and, simultaneously, ready to undertake the challenges of globalization" ${ }^{\prime 10}$.

Moving on to the second sequence, referred to in the introduction, the history proves, that almost parallel to the already-mentioned concepts of a nation, its views were represented quite differently. Two voices, belonging to R. Dmowski and B. Limanowski, have been heard in the last decades of our partitioning history. Regardless of speaking from different political orientations, these great politicians are harmonious in their full of pathos confessions regarding the sense of nationality. In the introduction to The Thoughts of a Modern Pole Dmowski states: "I am a Pole, that word means

5 Ibid, 144.

6 A. Olechowski, Wygrać przyszłość, Warszawa 1999.

7 Ibid, 10.

8 Ibid, 27.

9 Ibid, 132.

10 Ibid, 133. 
a lot. I am ... because ... I know the collective life of the nation, that ... I know the interests of Poland as a whole, the highest interests, for which one should sacrifice what one cannot sacrifice for personal matters"11. This declaration is accompanied by the confession of socializing Limanowski: "I am a nation, that is, I am aware of my national individuality, for it is a natural condition for my independence and the development of my abilities"12.

However, in the context of the international structures created in the interwar period, Fr.J. Roztworowski expresses his experience with national bonds by stating "... a nation is a product of blood and warmth of its native land, it is a concrete, colorful, vibrant reality, which not only speaks to the heart but clings to the incredible power of each of its particles and finds its resonance in each of its beatings" 13 .

Finally, the post-war period. Yet again, the forefront is occupied by the prominent figure of cardinal S. Wyszyński. In the final phase of his views, which, on a side note, have evolved to a certain extent, the nation appears as a "natural and primordial community of people, especially families ... bound in a higher community of historical space-time, in a living biological and psychological organism, realizing a kind of spiritual personality within itself" a specific "mystery of the nation"14. As a result of this specific national subjectivity, the plans of Divine Providence consist in calling upon the nation to fulfil special tasks in the service of man's ultimate destiny, as has happened in the history of the chosen people. These ideas, formed based on the Primate of the Millennium's own social and ethical thought, adopted an explicit life-related shape in the final phase of his pastoral work: interned for his steadfast attitude in defending the independence of Church against the atheistic power, he became a symbol of the nation's will to prevail in its national existence. It was also a significant

11 R. Dmowski, Myśli nowoczesnego Polaka, Lwów 1904, 13.

12 Cit. follow: J. J. Wiatr, Naród i państwo, Warszawa 1973², 157.

13 J. Roztworowski, Nacjonalizm, jego uprawnienia i etyczne granice, Przegląd Powszechny (1923)157, 101.

14 C. Bartnik, Chrześcijańska nauka o narodzie według prymasa Stefana Wyszyńskiego, Lublin 1982, 9, 11. 
contribution to the preparation of socio-political premises for the removal of the communist regime from our recent history.

In the conclusion of this cursory and selective review, an evident constatation may be deduced: in European history, in this case, with particular emphasis on Polish social thought, appears a clear opposition, one can say, an antinomy of two ideological trends. On the one hand, there is a constant presence of an ideological model, which, after two stages of metamorphosis, from the "cosmopolitan" (in 19th century) and "pan-European" (in 20th century) adopted the final form of a "globalist", as well as its opposing attitude of the spiritual monolith - a "patriot". Among the two model figures, the globalist embodies a distant and sophisticated strategist of the real, ultimately economic driving forces of social development, while the patriot represents a romantic idealist who elevates a beyond-individual national community spirit on the pedestal of life ideals. However, presenting these two opposing attitudes is not only relevant to the sociological diagnosis of changes in our nation's social consciousness but also reaches into the sphere of moral values. The question is whether the moral value reviving the attitude of the patriot, commonly referred to as "patriotism", retains its proper validity and significance as a model of conduct, also in the entering the historical audience age of globalization, or should it give way, or at least subordinate to a new standard of moral structure, in place of the nation affirming the new reality of the supranational "citizen", as a member of the emerging political superstructure, or a type of "megalopolis". This question is all the more relevant, as already in 1976, one of the Polish moralists wrote: "In the present day, the sense of patriotism has become blurred in the consciousness of many people. ... Young people often find it difficult to understand such a patriotic attitude of their fathers or grandparents ... they consider patriotism a relic of old times"15. Therefore - in short - is patriotism a social pathology or a living ideal?

15 S. Olejnik, Ojczyzna i patriotyzm w wizji wspólnoty międzynarodowej Jana XXIII, in: Kierunku prawdy, ed. B. Bejze, Warszawa 1976, 53. 


\section{THE NATION AS A SOCIAL ENTITY}

The outlined issue poses questions such as: what is a nation, what is its proper, collective reality and what is its place in the structure of social order. This problem cannot be solved by referring to the subjective, individual intuitions of outstanding individuals, even of such a great class as those mentioned in the introduction, all the more so, because they are divided by a chasm of radically different visions of the nation. An appropriate method of philosophical thinking, as well as manners of determining the object of research and further reflection set by the said method, comprise an indispensable tool aiding the goal of the dissertation. In the paper, this method will be based on the realistic premises of Christian ethics. That is why it is necessary to reach for preliminary data and determine what this reliable source of cognition says with regard to the nation.

In short, four conclusions may be provided. Thus, (1) a nation emerges from the preceding ethnic forms of collective existence (house, tribe, nationality) as its highest form. (2) However, with the moment it settles as a separate community, it functions and creates its own values by the power of its vital forces, which, while remaining in a separate, partially invisible world of the national spirit, find their external expression in experiencing a sort of national "We". (3) At the same time, however, history attests to the fact that, at a certain stage of its historical development, inspired by its representative elites, the nation becomes the subject of efforts to achieve political independence by creating a sovereign state. The ability to undertake such actions is a clear indication that the nation exists as a subject of its collective actions, as well as that this subjectivity should be considered a strong confirmation of its separate, real existential identity. (4) At last, it should be emphasized that a nation's aspiration to achieve its statehood results from the historical necessity to possess better living conditions and development, as well as to manifest its existence and cultural values. Therefore, it is not a sine qua non for being a nation. As history provides, an excellent confirmation of such conclusion comprises the fact that a nation is 
capable of maintaining the existence and vitality of social functioning, even after the loss of an external state organization.

To briefly conclude, the nation is not a type of "horizon line", as Olechowski repeats after the anonymous columnist, which, as everyone knows, "exists, but no one has managed to get close to it" or even more so, it is not a type of a "contractual value" created by individuals, as French Colonel Verdier tried to convince the young Polish lieutenant in the Brandstaetter's drama Ludzie z martwej winnicy [People from a Dead Vineyard $]^{17}$, but a living community, and simultaneously, a subject of social existence and action.

So much is said about the nation by historical experience, yet, the task ends on these findings. In turn, on the foundation of appropriate general philosophical premises of the based reflection, it is rational to examine what constitutes this creative force, functioning in the depths of the national spirit, a sort of life "principle", which embraces the whole of its life manifestations and actions, as well as defines its particular national image. In this deliberations, in the entire sense of the word, it is an "essential" issue, due to its key importance in penetrating the moral core of patriotism and allowing to draw normative conclusions from the said core.

It is clear that this is not an easy task, which additionally has been discussed for a long time, thus various solutions were presented. The one written by Coudenhove-Kalergi has been mentioned in the paper's introduction. It is necessary to omit the others in order to be able to develop one's own position on the matter more broadly. Coudenhove-Kalergi's thesis claims that the constitutive principle of a nation's identity constitutes the "national culture". The term indicates a complex of creations and institutions, among which one can distinguish language, religion, customs, literature, art and all that the national community creates in the course and with the purpose of spiritual formation of its members, according to the appropriate model of each national community. In this definition, two terms deserve to be emphasized. Firstly,

16 A. Olechowski, Wygrać przyszłość, op. cit., 133.

17 Cf. R. Brandstaetter, Teatr św. Franciszka oraz inne dramaty, Warszawa 1957, 203. 
the term "complex of creations and institutions" should be explored. Its essence assumes that these elements do not appear in the national culture as a mechanical collection of loosely related elements, but as a consistent cultural category with a specific spiritual expression. Secondly, it should be emphasized that, within the provided term, the merging of individual elements of national culture into an organic spiritual structure occurs in constant living contact with the process of shaping the spiritual image of the national community's individual members, simply the process of their becoming a Pole, a Hungarian or an Italian.

Two particular characteristics of the national culture have originated from this source as well. The national culture is first and foremost characterized by "spontaneity", or even "self-creativity" of its origin. The point is, that the national culture is not a creation of a certain institutional initiative, planned and controlled according to a specific model. The national culture is formed spontaneously through the power of talents of the nation's members, although this may happen under the influence of various external factors, adapted and incorporated by the members into a unified whole with its cultural specificity.

Therefore, on the extension of this spontaneous process of the national culture's formation appears another distinguishing feature which may be described as the "domesticity", or "familiarness" of the national culture. This feature emerges from the previous one, since the nation, by producing its own values from its spiritual and material resources or, by processing or incorporating certain borrowed elements into its vital tissue, simultaneously provides them with a unique colour. Growing into the spiritual climate of the culture formed in such a manner, from the very beginning of their lives in the closest social circles, particularly family and territorial ones, the members of the nation are saturated with its spiritual content, settle within it internally and consider as their "own" world, mainly due to the power of their emotional connection. A fuller explanation of the considerations implied by these words would comprise an indication of the relationship between the "nation" and the "homeland". 


\section{THE NATION VS. HOMELAND}

A nation, like anything human, resides in a certain place on Earth. In the case of a nation, such contact with Earth assumes a special form. A nation shapes its social image in a certain territory, which it populates as a permanent inhabitant. Houses and tribes wander, while nations, on principle, anchor in a larger or smaller area of habitable land. The occupied land passes from generation to generation, becoming a national legacy which, similarly to the family nest referred to as "patrimony", is considered by the members of the nation as their "homeland". In this form, the homeland transforms from a purely territorial category into a humanistic one. The nation's members, remaining in constant contact with their homeland, its peculiarity and natural colour since their early childhood, absorb these qualities as their spiritual property, as well as create a connection by the most subtle threads of their love for the country regarded as "homeland". Therefore, it is not surprising that, in the experiences of the nation's members, the homeland frequently appears more as the allure of native country than of the inhabiting people. This is how Mickiewicz viewed Lithuania in his poetic imagination, when "on the cobblestones of Paris", urged by the longing he returned "to these forest hills, to these green meadows, stretched wide over the blue Nemunas". This is not merely a description of nature, it is a part of the poet's soul, formed by the impersonated spirit of his native nature.

Thus, in the conclusion of the outlined reflection, it can be stated that, although the nation does not identify itself with the homeland, nor does the child identify itself with the cradle in which it grows and exhausts its parents to their own joy, they are bound together by undeniable, profoundly deep and creative relations. The nation finds the material basis of existence in its homeland, from which it derives considerable resources of possessions, which provides it with certain building materials for the development of the national culture, leaving a particular, unique stigma. In short, the nation lives within its homeland, while the homeland provides a valuable contribution to the culturally creative process of national, social existence. 
Findings regarding the essential structure of a nation, extended by the expression of close ties between the nation and homeland, create logical premises facilitating the formulation of a definitive answer to the following questions: (1) what is the reason for the nation's transformation into a moral good; (2) what is its place in the structure of the moral order.

\section{THE NATION AS A MORAL GOOD}

The former question can only be answered briefly. A nation is not a beyond-personal, autonomous hypostasis or even a chimaera. A nation consists of a community of human persons, whose subjectivity and moral dignity become the principles which determine the meaning and moral destiny of any community. They are intended to create conditions necessary for the complete development of a human person. Thus, a national community emerges as one whose right to exist, as well as the sense of this existence, are expressed in the formation of an appropriate spiritual image of its integrated individuals. Therefore, precisely this internal relationship, which directs the national community towards the good of the human person, renders the nation not only a fascinating social entity but also adopts the form of social moral good. The analogy which exists between the human person and the nation will be used in order to illustrate and, simultaneously, rationally support this claim. Man as a person comprises a moral good, however, not in the sense of a model or ideal of moral conduct, such as justice. I turn, man as a person is a moral good because he is a rational subject of action who, due to his nature's relation with his moral self-improvement, is thus subject to the moral necessity of following moral patterns, that is, moral values such as justice, truthfulness or honesty. Similarly, a nation does not comprise a moral good in the sense of an ideal model of conduct but rather represents it as a collective subject that enables the human person to realize the corresponding moral perfection. The nation is not assigned any other meaning of the concept of moral good. Nevertheless, since this is the moral status of a nation, there is room for 
the "nation's ethics", and within its framework - a consideration of the content of this moral virtue referred to as "patriotism".

\section{THE MORAL ETHOS AND LIMITATION OF PATRIOTISM}

The notion of patriotism as a moral virtue transfers the paper's deliberations into the sphere of the man's consciously shaped, personal attitudes. However, the spiritual content of this attitude is determined by man's approach to the nation. Thus, at the end of this arduous reflection, we have come to the belief that nation comprises a moral good - in general, and, above all, for the members of this national community, which subsequently leads to the conclusion that this good should become the object of the members' acceptance, spiritual integration and readiness to do anything that this good preserves in good condition - which develops and multiplies it. Such a spiritual attitude in the language of ethics is referred to as the "love of homeland" or nation, while in an appropriately high level - patriotism.

However, the simplicity of this phrase presupposes a certain condition, namely - a suitable degree of national awareness among individual members of the national community. Meanwhile, it is known from experience that the realization of the spiritual bond with the nation and its cultural identity in individual members, or even the entire sections of a nation may not occur. Therefore, an important moral postulate of patriotism and its practical realization consists of activities which can be generally described as "national education", most frequently understood as the broad social programs of spreading national awareness. They hold lesser importance for nations which live in the conditions of their stable political organization. However, it is different with regard to nations condemned to exist within the borders of a foreign statehood, particularly when it is unfavourable, hostile, or even strives for their extermination It suffices to recall E. Hartmann's rücklichtslos germanisieren slogan of the Kulturkampfin the Prussian partition ${ }^{18}$.

18 M. Morawski, Podstawy etyki i prawa, Kraków 1930, 274. 
Patriotism, in all its moral sublimity, has its boundaries. No nation comprises a "lonely island" on Earth. It always remains in constant, direct or indirect relations with other nations. Depending on the political or ethnic circumstances, these relations may assume the form of a neighbourly coexistence of equal nations or a symbiosis of the national minority with the host nation. However, in both cases, and all the more so, in conflicting arrangements of opposing nations, patriotism retains its authentic moral form, on condition that the love for one's nation is combined with an appropriate attitude towards other nations. This indicates that authentic patriotism never accepts the attitude commonly referred to as "nationalistic chauvinism", i.e., certain national megalomania which distorts the cult of one's nation by saturating it with elements of contempt - in the most favourable scenario, by ignoring the other nation. If the basic demand of patriotism comprises the care for, as well as an active engagement in defending the interests of one's nation, then it is also a necessary requirement to respect the similar interests of foreign nation's members. Only with such an approach, in specific situations, it is possible to investigate what does justice demand, as well as what conditions does it impose.

For the time being, a general definition of the moral value of patriotism will suffice. However, the said definition will be completed in the context of a subsequent issue, in which the phenomenon of threats to the national culture will be considered

\section{PATRIOTISM AND THREATS TO THE NATIONAL CULTURE}

Since, as has been presented in the course of considerations to date, the social core of a nation's identity and the source of its vitality consist in the national culture, then the greatest threat to this identity would be the one aimed at the nation's culture. The awareness of such a threat has accompanied the Polish social thought since the first decades of the nation's partitioning history. K. Libelt, inspired by the "cosmopolitan wise men", who regarded "the national relations and interests" as "limitation of progress, detrimental to 
humanity ${ }^{19}$, immediately translated his ethos of patriotism into the language of the most important duties of his contemporary Pole towards their homeland. They will be shortly presented in the following section. Libelt emphasized the importance of the homeland's cult, urged the realization of true democracy by allowing the widest sections of society to participate in the material and spiritual goods of the national culture, encouraged the love of the native language and was concerned about its purity, warned against the blind imitation of foreign patterns, and ordered the strengthening and deepening of the bond between the nation and religion, in which he saw a particularly valuable good of the national community.

Nearly 150 years later, a similar initiative was undertaken by cardinal S. Wyszyński. The man saw the threat to the national culture in the organized efforts to secularize and demoralize the broad masses of society in order to undermine the nation's religious life, as well as to sever its bond with the Church, the consequence of which comprised of the nation's disconnection from the traditions and country's history, and ultimately, the weakening of Christian and Polish memory, as well as the straining of the national life's biological basis by mass slaughtering the unborn ${ }^{20}$. The authors contemporary to the Primate of the Millennium indicated the ambivalent character of the so-called "mass culture" which, in addition to certain positive qualities, causes more harm to the national culture by spreading cultural infantilism in its somewhat vulgar form and various ways, with the general support of the social media ${ }^{21}$. Such an understanding of the situation resulted in the origin of the pastoral campaigns, extended by Wyszyński, which aimed at deepening the religious and moral life of the society, and, at that period, simultaneously comprised the attainable actions which strengthened the foundations of the national culture.

19 K. Libelt, Samowładztwo rozumu i objawy filozofii słowiańskiej, op. cit., 6.

20 C. Bartnik, Chrześcijańska nauka o narodzie według prymasa Stefana Wyszyńskiego, op. cit., 7.

21 J. S. Pasierb, Kościół i aktualne przemiany kultury polskiej, in: Człowiek we wspólnocie Kościoła, ed. L. Bartel, Warszawa 1979, 336. 
The structural and political transformations initiated shortly after the death of cardinal Wyszyński, the more recent inclusion of Poland in the supranational structures of the European Union, and, above all, the rapidly developing process of "globalization" contribute to the commonness of the question regarding the type of future these changes herald for the national culture. Do these changes, or more importantly, does the globalization process open the national culture to the prospects of better conditions for shaping the identities of nations involved, or does it raise fears that it would place the nation in front of new, even more dangerous threats? In short, will the "new times" constitute a chance for the national culture to grow, or will they foreshadow a confining?

The prerequisite for a correct answer to these questions consists in a proper understanding of the situation which is merely emerging, and above all, in establishing what the Marxists in their time described as the "main link" in the list of specific factors which fall within the scope of the intended action. From this point of view, presented in the paper's introduction, A. Olechowski's perception of this matter appears as blatantly one-dimensional. Admittedly, a substantial amount of criticisms of the contemporary Polish reality, as well as certain reform proposals regarding detailed improvements in social life deserve recognition. After all, these positive inspirations have been incorporated into the economic framework of the "free market" category, subject to the law of productive efficiency and maximum profit. As a result, the social effects of globalization (most importantly - the issue of unemployment) disappeared from his sight, all the more so, that he displayed no understanding of the pathologies caused by this process in the cultural and spiritual spheres of the nation's life.

The authors of the report on globalization, commissioned by the German Episcopate ${ }^{22}$, adopted a more factual stance on this issue. As an initial point, they assumed the distinction of four fundamental levels: economic, political, spiritual and cultural, as well as ecological,

22 Die vielen Gesichter der Glogalisierung - Perspektiven einer menschengerechten Weltordnung, Bonn 1999. 
which are methodologically relevant in the process of globalization. However, with the general approval of globalization as a tendency to integrate Europe, they admit that globalization, considered from the perspective of its animating ideology, does not appear to be a neutral worldview formation. On the contrary, the issues discussed in the following part of the paper are noticeably oriented in this respect. For this reason, in the "Third World" and Muslim countries, globalization is perceived as a form of Western European, secularized imperialism. The wakening opposition against globalism is indicated in conflicts which have already risen on this ground ${ }^{23}$.

However, a critical remark must be made about all of these, in fact, correct constatations: they stop halfway, without reaching the roots of evil. To adequately illustrate globalization with regard to the national culture, it is necessary to reach for its ideological sources. They are hidden in theories proclaimed by the trend's representatives (it suffices to recall the name of L. Mises and M. Rothbart from the circle of the so-called libertarianism ${ }^{24}$ ) to become convinced that globalization is not merely an economic process. Globalization possesses a noticeable philosophical and anthropological foundation, which constitutes a basis for social science, whose fundamental principles were formulated in the spirit of extreme materialistic and naturalistic liberalism. The ideology elevates to the pedestal of significant values a secular model of life, imbued with various forms of postulating atheism and moral permissivism, occasionally a perverse distortion of a healthy moral sense (for instance, homosexual "marriages"), covered by the figurative fig leaf of the archaic notion of human freedom. A liberal vision of a secular, one-dimensional and spiritually flattened society constitutes the integration and a certain culmination of the built worldview's elements.

In turn, one may ask whether this is a purely theoretical construction, similarly to Plato's Republic, or an outlook inspiration for

23 Ibid, 34.

24 L. V. Mises, Liberalism in the classical Tradition, transl. R. Raico, The Foundation for Economic Education, Irvington 1985, 10. Cf. R. Legutko, Spory o kapitalizm, Kraków 1994, 168-174, 202-203. 
a programme of actual activities, both remotely directed or undertaken by individuals or social organizations animated by this spirit. In this respect, the experience should be given the deciding voice. Guided by this directive, based on the observations of the currently occurring life changes within the European societies, including the Polish one, it is evident how effective the progress of globalization is with regard to the realization of the vision of a secular society, which is economically dominated by supranational monopolies, whose worldview and morals are moulded in the fashion of a pseudo-progressive model of a man and which, in the name of unordered freedom, advocates the desire for the interim use and possession. At this stage, this is executed through legislative acts (for instance, the legalization of homosexual couples, euthanasia, "therapeutic cloning"), or, if allowed by the political arrangements, the administrative orders, while on a wider scale - in the form of masked indoctrination conducted primarily by means of the widespread media.

Regardless of the practicality of the globalizing ideologization methods, it is clear that the impact of all these measures of advocating the globalizing cultural models must ultimately result in the strain on the authentic state and social vitality of the historically shaped national cultures. Therefore, the modern form of globalization, perceived through the prism of its animating ideology, does not constitute an opportunity but rather a serious threat to the national cultures, by incorporating the embryos of cultural atrophy, as well as the effacement of the national identity. Thus, for a nation conscious of its identity, the globalization comprises a dramatic challenge to undertake action in order to preserve or multiply its cultural heritage in confrontation with a globalist ideology. In the current socio-political arrangements, the historical role of the nation consists in the creation of its proper, spiritual and cultural conditions for the authentic development of the human person.

Such a postulate reduces these deliberations to the well-known areait is simply necessary to refer to the initiated by Libelt, and continued by cardinal S. Wyszyński slogan regarding the defense of the national identity of the culture against the threats of liberal secularism, permeating the globalization fundaments of the worldview, which, as the presented 
analysis reveals - is still valid. The mobilizing factors are provided by the aforementioned protagonists of the national identity, represented by K. Libelt and S. Wyszyński, not only as encouragement that this should be done but also as an example of how it should be executed. After all, many of the Libelt's indications remain valid even now. Nevertheless, the deontological essence of contemporary patriotism must consist in the application of its general values and imperatives to the situation and needs of our times. It is primarily a matter of sensitizing the national conscience to the dilemmas and difficulties emerging in the course of national life, as well as the necessity to undertake an appropriate, ethical understanding of the imposed attitude's national good.

\section{CONCLUSIONS}

However, these patriotic tasks, which the modern generation directly encounters, must correspond with the awareness of the centuries-long, currently particularly vital process of cultural convergence between nations and the occurring between them phenomena of ethnic osmosis. Globalization constitutes only one, additionally ideologically warped manifestation. Therefore, the paper's considerations focusing on the ethical aspects of the nations' identities, in the current civilizational age, require a logical consequence in the form of supplementation through the reflection on two great themes. One of the said themes would expand the concept of the national integration based on the cultural identity (the idea of such a transnational "ethnarchy" was already outlined in the 19th century by the Italian Jesuit L. d'Azeglio Taparellii' ${ }^{25}$, while the other would strive to develop the notion of patriotism, by incorporating into its content broader ethical norms, presenting the moral values of mutual respect and cooperation of the integrated nations within the community. The significance of the patriotic ethos'implications requires that they be at least signaled, while the diversity of their content obligates to regard them as the subject of a separate study.

25 R. Jacqzin, Taparelli, Paris 1943, 238-241; A. Verdross, Le probleme de l'organisation internationele, in: Miscellanea Taparelli, Paris 1964, 529-534. 


\section{BIBLIOGRAPHY}

Bartnik C., Chrześcijańska nauka o narodzie wedtug prymasa Stefana Wyszyńskiego, Lublin 1982.

Brandstaetter R., Teatr św. Franciszka oraz inne dramaty, Warszawa 1957.

Coudenhove-Kalergi R. N., Pan-Europa, Wien - Leipzig 1924.

Die vielen Gesichter der Glogalisierung - Perspektiven einer menschengerechten Weltordnung, Bonn 1999.

Dmowski R., Myśli nowoczesnego Polaka, Lwów 1904.

Jacqzin R., Taparelli, Paris 1943.

Legutko R., Spory o kapitalizm, Kraków 1994.

Libelt K., Samowtadztwo rozumu i objawy filozofii stowiańskiej, Warszawa 1967.

Mises L. V., Liberalism in the classical Tradition, transl. R. Raico, The Foundation for Economic Education, Irvington 1985.

Morawski M., Podstawy etyki i prawa, Kraków $1930^{4}$.

Olechowski A., Wygrać przysztość, Warszawa 1999.

Olejnik S., Ojczyzna i patriotyzm w wizji wspólnoty międzynarodowej Jana XXIII, in: Kierunku prawdy, ed. B. Bejze, Warszawa 1976.

Pasierb J. S., Kościót i aktualne przemiany kultury polskiej, in: Cztowiek we wspólnocie Kościota, ed. L. Bartel, Warszawa 1979.

Roztworowski J., Nacjonalizm, jego uprawnienia i etyczne granice, Przegląd Powszechny (1923)157, 87-117.

Verdross A., Le probleme de l'organisation internationele, in: Miscellanea Taparelli, Paris 1964, 529-534.

Wiatr J. J., Naród i państwo, Warszawa $1973^{2}$.

Tadeusz Ślipko

DOI: $10.21697 /$ spch.2020.56.S2.14 